\title{
Biogeochemistry of Critical Metals and the Flinders Ranges Natural Laboratory
}

\author{
JOËL BRUGGER ${ }^{1}$, FRANK REITH ${ }^{1,2}$, \\ ALEXANDER KALINTSEV ${ }^{1}$, \\ SANTONU KUMAR SANYAL ${ }^{1,2}$, JEREMIAH SHUSTER ${ }^{1,2}$ \\ AND BARBARA ETSCHMANN ${ }^{1}$
}

${ }^{1}$ School of Earth, Atmosphere and Environment, Monash University, Clayton 3800, Victoria, Australia. joel.brugger@monash.edu

${ }^{2}$ School of Biological Sciences, The University of Adelaide, Adelaide, South Australia 5005, Australia.

${ }^{3}$ CSIRO Land and Water, Glen Osmond, South Australia 5064, Australia.

The regolith is an important host for economic concentrations of critical metals such as REE, $\mathrm{U}, \mathrm{Ni}$, and Co. The (bio)geochemical weathering of rocks from ore deposits is a key process behind these supergene enrichments.

The Flinders Ranges in South Australia is a natural laboratory to study REE and $U$ mobility under (bio)geochemical weathering conditions in a semi-arid environment. The Mount Painter basement inlier contains large amounts of Mesoproterozoic granitic rocks that are enriched in $\mathrm{REE}+\mathrm{U}$. The inlier is still tectonically active, (raising at $\sim 1 \mathrm{~mm} /$ year), resulting in intense erosion and a variety of weathering styles. Because of its high content of radioactive elements, the Mount Painter inlier is warmer than the blanketing sediments; this has resulted in a long history of hydrothermal activity, driven by tectonics and water availability, which is still on-going as demonstrated by the Paralana Hot Springs (ca. $60^{\circ} \mathrm{C}$ ). This hydrothermal activity is also responsible for the formation of numerous small $\mathrm{U} \pm \mathrm{REE}$ deposits that were exploited for radium in the 191030s and prospected for $U$ in the 1950-70s. All historic mining activity was small-scale, and plenty of undisturbed mineralisation remains at the near surface. Additionally, highly contaminated mine wastes have remained undisturbed for up to 90 years because these areas are now protected as part of the Arkaroola Wilderness Sanctuary.

We will review past and on-going collaborative work with Frank Reith in the Flinders ranges: (i) proximal detrital gold grains from small gold showings displayed an remarkably active microbial activity; (ii) microscale mineralogical and possibly biological controls on macro-scale movements of REEs in a thin weathering profile within a REE+HFSE-rich granite; (iii) a first look at microbial communities and functions in U-contaminated soils and tailings in the Mount Painter inlier. 